\title{
EHMTI-0022. Pharmacokinetic variability of drugs used for prophylactic treatment in migraine
}

\author{
P Pavbro , P Tfelt-Hansen \\ From 4th European Headache and Migraine Trust International Congress: EHMTIC 2014 \\ Copenhagen, Denmark. 18-21 September 2014
}

\section{Introduction}

In order to evaluate pharmacokinetic variability of preventive migraine drugs we have in this study reviewed single dose studies.

\section{Methods}

PubMed was searched for each drug with the "drugs generic name", "pharmacokinetics", and "single dose". Variability was calculated as coefficient of variation (CV).

\section{Results}

A total of 105 single-dose kinetic studies were reviewed but only a few representative results are presented:

Extended release propranolol $160 \mathrm{mg}(\mathrm{n}=2)$ : $\mathrm{CV}$ for Cmax $=45-55 \%$, and CV for AUC: $43-48 \%$. Propranolol $80 \mathrm{mg}(\mathrm{n}=1)$ : Ratio for $\mathrm{Cmax}=14$ and ratio for AUC = 24. Metoprolol $100 \mathrm{mg}(\mathrm{n}=2)$ : $\mathrm{CV}$ for $\mathrm{Cmax}=23-64 \%$, and CV for AUC: $26-75 \%$. Metoprol $100 \mathrm{mg}(\mathrm{n}=1)$ : Ratio for $\mathrm{Cmax}=8$ and ratio for $\mathrm{AUC}=23$. Extended release divalproex 500 and $1000 \mathrm{mg}(\mathrm{n}=2)$ : $\mathrm{CV}$ for $\mathrm{Cmax}=12$ 21\%, and CV for AUC: $19-30 \%$. Topiramate $100 \mathrm{mg}$ $(\mathrm{n}=1)$ : CV for $\mathrm{Cmax}=16 \%$ and CV for $\mathrm{AUC}=14 \%$. Candesartan $16 \mathrm{mg}(\mathrm{n}=2): \mathrm{CV}$ for $\mathrm{Cmax}=31-34 \%$ and CV for AUC 26-28\%.

\section{Conclusion}

A coefficient of variation of a pharmacokinetic parameter above $40 \%$ is considered to be high. The results for the AUCs of propranolol and metoprolol show high variability; and it is not likely that the migraine patients can be treated with a fixed dose-schedule with these two drugs. Instead dosing should in each case be tailored to the individual migraine patients.

No conflict of interest.

University of Copenhagen, Danish Headache Center in Glostrup, Glostrup, Denmark

C 2014 Pavbro and Tfelt-Hansen; licensee Springer. This is an Open Access article distributed under the terms of the Creative Commons Attribution License (http://creativecommons.org/licenses/by/2.0), which permits unrestricted use, distribution, and reproduction in any medium, provided the original work is properly cited.
doi:10.1186/1129-2377-15-S1-G36

Cite this article as: Pavbro and Tfelt-Hansen: EHMTI-0022.

Pharmacokinetic variability of drugs used for prophylactic treatment in migraine. The Journal of Headache and Pain 2014 15(Suppl 1):G36.

Submit your manuscript to a SpringerOpen ${ }^{\bullet}$ journal and benefit from:

- Convenient online submission

- Rigorous peer review

- Immediate publication on acceptance

- Open access: articles freely available online

- High visibility within the field

- Retaining the copyright to your article

Submit your next manuscript at $\boldsymbol{~ s p r i n g e r o p e n . c o m ~}$ 